\title{
PERAN KEPALA DESA DALAM MENINGKATKAN PARTISIPASI MASYARAKAT DALAM PEMBANGUNAN DESA TRADISIONAL DI DESA JULAH KECAMATAN TEJAKULA KABUPATEN BULELENG- BALI
}

\author{
Luh Mulyani, Luh Deni Sri Wahyuni, Ni Wayan Ayuk Suantari, Nabila Safitri, \\ Kadek Arik Arminiasih, Komang Ariati \\ Jurusan Akuntansi, Universitas Pendidikan Ganesha, Singaraja, Bali, Indonesia
}

\begin{abstract}
Abstrak
Penelitian ini bertujuan untuk mengnvestigasi partisipasi masyarakat Desa Julah dalam pembangunan dan peran kepala desa dalam meningkatkan partisipasi masyarakat Desa Julah. Penelitian dilakukan dengan menerapkan metode penelitian kualitatif dengan teknik pengumpulan data wawancara dan observasi. Hasil penelitian menunjukkan bahwa tingkat partisipasi masyarakat di Desa Julah dalam pembangunan sudah mulai meningkat walaupun masih sedikit. Masyarakat Desa Julah masih ada yang belum merasa memiliki tanggungjawab untuk sama-sama memajukan desa. Dimana sebuah desa akan dapat maju apabila ada partisipasi dari masyarakat. Sementara itu, ditemukan bahwa Kepala Desa Julah yang telah menjabat selama satu tahun telah melaksanakan tugas dan tanggung jawabnya untuk memajukan desa dan meningkatkan tingkat partisipasi masyarakat desa Julah dalam pembangunan. Selama ini, Kepala Desa telah berusaha untuk mengakomodir setiap saran dari masyarakat hanya saja belum secara merata.
\end{abstract}

Kata kunci: peran kepala desa; partisipasi masyarakat; pembangunan desa; desa tradisional

\begin{abstract}
This study aims to investigate the participation of Julah Village community in development and the role of the village head in increasing the community participation of Julah Village. The study was conducted by applying qualitative research methods to interview and observation data collection techniques. The results showed that the level of community participation in the village of Julah in development had begun to increase although it was still small. There are still Julah villagers who do not feel they have the responsibility to work together to advance the village. Where a village will be able to progress if there is participation from the community. Meanwhile, it was found that the village head of Julah who had been in office for one year had carried out his duties and responsibilities to advance the village and increase the level of participation of Julah's village community in development. During this time, the Village Head has tried to accommodate every suggestion from the community, it's just not evenly distributed.
\end{abstract}

Keywords: the role of the village head; society participation; village development; traditional village

\section{Pendahuluan}

Dalam era pembangunan seperti sekarang ini, Pemerintah Indonesia telah mewacanakan untuk melakukan pembangunan Nasional secara merata. Bukti dari dedikasi pemerintah untuk melakukan pembangunan secara merata ini telah dimulai dari struktur terkecil dari organisasi pemerintahan yaitu dari Pemerintahan Desa. Undang-Undang Dasar Negara Kesatuan Republik Indonesia tahun 1945 Pasal 18 B ayat (2) yang berbunyi "Negara Mengakui dan Menghormati kesatuan-kesatuan masyarakat hukum adat beserta hak-hak tradisionalya sepanjang masih hiduo dan sesuai dengan perkembangan masyarakat dan prinsip Negara Kesatuan Republik Indonesia yang diatur dalam Undang-Undang". Dengan demikian dapat dikatakan bahwa Negara mengakui adanya masyarakat adat atau desa yang kemudian diberikan kewenangan (otonomi) untuk menyediakan pelayanan kebutuhan dasar dan pelayanan pengembangan usaha ekonomi masyarakat lokal. Menurut Undang-Undang No. 6 Tahun 2014 tentang Desa, kewenangan desa meliputi kewenangan di bidang pelaksanaan pembangunan desa, Pembinaan Kemasyarakatan desa, dan Pemberdayaan masyarakat desa berdasarkan prakarsa masyarakat, hak asal-usul, dan adat istiadat desa. 
Dalam pelaksanaan pemerintahan desa tentu tidak terlepas dari adanya peran Kepala Desa yang bertugas untuk menyelenggarakan pemerintahan Desa, melaksanakan pembangunan desa, Melakukan pembinaan kemasyarakatan desa, dan melakukan pemberdayaan masyarakat desa (Menurut UU No. 6 Tahun 2014). Dimana seorang kepala desa diharapkan mampu mengakomodasi aspirasi masyarakat, mewujudkan peran aktif masyarakat untuk turut serta bertanggungjawab terhadap perkembangan kehidupan bersama sebagai sesame warga desa. PP No 72 tahun 2005 Desa, menyatakan terdapat prinsip dasar sebagai landasan pemikiran pengaturan mengenai desa yaitu : Keanekaragaman, Partisipasi, Otonomi asli, Demokratisasi, dan Pemberdayaan Masyarakat. Sehingga disinilah peran Kepala Desa untuk dapat meningkatkan peran partisipasi masyarakat desa guna memajukan pembangunan Desa. Menurut Permendagri No 66 Tahun 2007 tentang Perencanaan Pembbangunan Desa, Pembangunan di Desa merupakan model pembangunan partisipatif adalah suatu system pengelolaan pembangunan di desa bersama-sama secara musyawarah, mufakat, dan gotong royong yang merupakan cara hidup masyarakat yang telah lama berakar budaya di wilayah Indonesia.

Melaksanakan Pembangunan Desa bukan hanya tugas dari Kepala Desa, tetapi merupakan tugas dari seluruh warga desa. Pembangunan Desa akan sulit terlaksana apabila tingkat partisipasi masyarakat masih rendah. Meskipun Pemerintah tengah gencar mensosialisasikan dana Desa yang ditujukan agar pembangunan tiap desa meningkat namun tetap saja apabila masyarakatnya acuh tak acuh maka dana desa yang telah diberikan pun akan sulit direalisasikan sesuai peruntukannya. Misalnya pada Desa Tua atau Desa Tradisional, Pembangunan Desa bukan berarti akan merusak kearifan lokal yang ada. Sebagai Desa yang bernilai sejarah, tentu saja Desa tua memiliki banyak tradisi budaya yang khas yang patut dipertahankan bukan semata-mata untuk kepentingan pariwisata tetapi lebih jauh sebagai asset untuk menelusuri sejarah masa lalu. Dapat mewujudkan pembangunan pada Desa tradisional dengan tetap mempertahankan nilai budaya dan kearifan lokal yang ada merupakan pencapaian yang hanya akan dapat dicapai apabila terdapat sinergritas antar kepala desa, Kepala adat dan masyarakatnya untuk memajukan Desanya.

Penelitian ini dilaksanakan di salah satu desa tua yang masih ada di Bali Utara, Tepatnya yaitu di Kecamatan Tejakula Kabupaten Buleleng, Desa ini Bernama Desa Julah. Desa Julah merupakan salah satu desa yang masih ajeg dan lestari kearifan lokalnya sampai saat ini. Di desa Julah banyak ditemukan peninggalan bersejarah seperti prasasti. Sebagai Desa tua, Desa Julah juga dapat dikatakan sebagai desa yang masih tertinggal. Pembangunan di Desa Julah masih belum dapat dilakukan secara merata. Berdasarkan hasil wawancara yang peneliti lakukan, ditemukan salah satu permasalahan yang terjadi di desa ini ialah tingkat partisipasi masyarakatnya yang masih rendah. Masyarakat hanya menyerahkan tanggungjawab kepada kepala desa, Sehingga Kepala Desa di Desa Julah kesulitan untuk bisa menampung aspirasi masyarakat. Masyarakat di Desa Julah memiliki tingkat partisipasi yang rendah dalam organisasi pemerintahan Desa. Saat dilaksanakan rapat Desa Masyarakat tidak mau menyampaikan aspirasinya atau masyarakat Julah sebut dengan "Ngekoh Ngomong". Penelitian ini menarik dilakukan untuk mengetahui apakah peran dari kepala desa di Desa Julah telah maksimal dilakukan untuk Membangun Desa. Apakah ada penyebab mengapa tingkat partisipasi masyarakat di Desa Julah masih rendah. Dan apakah ada solusi yang dapat diterapkan kepala desa untuk dapat meningkatkan tingkat partisipasi masyarakat desa Julah guna melakukan pembangunan desa yang lebih baik dengan tetap menjaga kearifan lokal yang ada.

Berdasarkan latar belakang yang diuraikan diatas, adapun permasalahan yang didapat adalah bagaimanakah partisipasi masyarakat Desa Julah dalam pembangunan dan bagaimana peran kepala desa dalam meningkatkan partisipasi masyarakat Desa Julah.

\section{Pembahasan}

\subsection{Partisipasi masyarakat Desa Julah Dalam Pembangunan}

Partisipasi masyarakat dalam pembangunan sangat diperlukan guna meningkatkan pembangunan desa. Untuk mengetahui peran partisipasi masyarakat Desa Julah dalam 
pembangunan kami mewawancarai pihak-pihak seperti Kepala Desa Julah, Kelian adat (Tetua Adat) di Desa Julah, Kaur Pembangunan di Desa Julah, dan masyarakat yang ada di Desa Julah masing-masing dua orang untuk setiap dusun yang ada yaitu di Dusun Kawanan, Dusun Kanginan dan Dusun Batu Gambir. Untuk hasil dari wawancara kami dapat dilihat hasilnya sebagai berikut:

Menurut Hoofsteede dalam Khairuddin (2000: 125) membagi partisipasi menjadi tiga tingkatan, antara lain:

\section{Partisipasi inisiasi (initiation participation)}

Adalah partisipasi yang mengandung inisiatif dari pemimpin desa, baik formal maupun informal, ataupun dari anggota masyarakat mengenai suatu proyek, yang nantinya proyek tersebut merupakan kebutuhan bagi masyarakat.

Adapun tanggapan yang diberikan oleh informan yaitu Kepala Desa di Desa Julah Bapak Ketut Kanis Tanaya yang menyatakan sebagai berikut:

"Saat ini saya sedang merencanakan renovasi bale banjar dan pembuatan TPS

(Tempat Pembuangan Sampah) sebenarnya program ini sudah direncanakan dari perbekel sebelumnya tetapi belum terlaksana karena permasalahan tanah dan perjanjian tetapi sekarang sudah deal sehingga bisa saya lanjutkan."

Kepala desa memang memiliki peranan dalam memutuskan suatu proyek yang akan bermanfaat bagi masyarakat kedepannya. Namun peran masyarakat juga sangat diperlukan dalam pelaksanaan rencana proyek yang dibuat kepala desa. Adapun tanggapan yang diberikan oleh informan yaitu Bapak Komang Suweca selaku Kaur Pembangunan di desa Julah menyatakan sebagai berikut:

"Partisipasi masyarakat sekarang setidaknya ada perbaikan meskipun masih sedikit. Dalam satu tahun kepemimpinan kepala desa yang sekarang ada beberapa proyek yang sudah terlaksana namun ada pula yang masih dalam proses. Dalam setiap proyek yang dilaksanakan, LPM bersama Kepala Desa dan Kepala Dusun ikut memantau perkembangan proyek sekaligus berdiskusi dengan masyarakat.

Adapun tanggapan yang diberikan oleh informan yaitu Bapak Ketut Sidemen selaku Kelian Adat (Tetua) di Desa Julah menyatakan sebagai berikut:

"Kepala desa datang pada saat paruman di pura yang dikelola oleh adat, dimana pada saat paruman tersebut kepala desa dapat mendiskusikan tentang masalahmasalah desa, perbaikan apa yang akan dilaksanakan. Kepala Desa saat ini masih berfokus dalam pembangunan ekonomi, untuk kerjasamanya dengan adat sudah cukup namun masih perlu ditingkatkan lagi.

Adapun tanggapan dari salah satu warga di Dusun Kawanan yaitu Bapak Ketut Sedeng menyatakan sebagai berikut:

"Menurut saya Partisipasi masyarakat Desa Julah termasuk saya sudah cukup baik. Saya pada saat Kepala Desa yang sekarang ini menginstrusikan untuk diadakan gotong royong pembersihan desa saya telah ikut berpartisipasi. Meskipun masih ada pula masyarakat yang ikut berpartisipasi. Proyek pembangunan Desa yang sekarang juga semakin baik. Sekarang didepan rumah saya sudah dibuatkan got dan saya juga berpartisipasi dalam penggalian got tersebut".

Adapun tanggapan lainnya dari warga Dusun Kawanan mengenai Partisipasi masyarakat dalam pembangunan menurut Made Ayu Ningsih menyatakan sebagai berikut: 
"Menurut saya partisipasi warga di dusun kawanan dalam menanggapi setiap proyek yang dibuat oleh Kepala Desa sejauh ini masyarakat sudah merasakan manfaatnya seperti perbaikan jalan, dan pemasangan paping". jalannya kini sudah diisi paping.

Adapun tanggapan dari salah satu warga dari Dusun Kanginan mengenai Partisipasi masyarakat dalam pembangunan menurut Nyoman Mirah menyatakan sebagai berikut: "Menurut saya partisipasi warga di dusun Kanginan dalam menanggapi setiap proyek yang dibuat oleh Kepala Desa sejauh ini masyarakat sudah merasakan manfaatnya ya seperti kalian liat sendiri yaitu ada perbaikan jalan, pembuatan pemasangan paping". disini saya selaku warga Dusun kanginan melihat proyek yang dibuat oleh kepala desa ini sangat bermanfaat bagi warga semua seperti dulu jalanan disini sangat rusak, sekarang sudah di puping".

Adapun tanggapan lainnya dari warga Dusun Kanginan mengenai Partisipasi masyarakat dalam pembangunan menurut Putu Warcana menyatakan sebagai berikut:

"Menurut saya partisipasi warga di dusun Kanginan dalam menanggapi setiap proyek yang dibuat oleh Kepala Desa sejauh ini masyarakat sudah merasakan manfaatnya seperti perbaikan jalan,dulu jalan belum di puping sekarang jalan sudah dipuping".

Adapun tanggapan dari salah satu warga dari warga Dusun Batu Gambir mengenai Partisipasi masyarakat dalam pembangunan menurut Wayan Gina menyatakan sebagai berikut:

"Menurut saya partisipasi warga di dusun Batu Gambir dalam menanggapi setiap proyek yang dibuat oleh Kepala Desa sejauh ini masyarakat belum merasakan manfaatnya seperti,pembgian air PAM yang belum merata ke Dusun Batu Gambir karena alasannya dusun batu gambir jauh diatas bukit”.

Adapun tanggapan lainnya dari warga Dusun Batu Gambir mengenai Partisipasi masyarakat dalam pembangunan menurut Ketut Carini menyatakan sebagai berikut:

"Menurut saya partisipasi warga di dusun Batu Gambir dalam menanggapi setiap proyek yang dibuat oleh Kepala Desa sejauh ini masyarakat belum merasakan apa-apa, karena untuk mendapatkan air saja kami disini sangat susah, apalagi untuk pembangunan yang lain dusun kami belum mendapat apa-apa.

\section{Partisipasi legitimasi (lagitimation participation)}

Partisipasi pada tingkat pembicaraan atau pembuatan keputusan tentang proyek tersebut. Adapun tanggapan yang diberikan oleh informan yaitu Kepala Desa di Desa Julah Bapak Ketut Kanis Tanaya yang menyatakan sebagai berikut:

"ketika saya mengadakan rapat masyarakatnya semua datang tetapi belum yang mau berbicara, karena sulit mengarahkan orang-orangnya untuk maju dan saya juga harus bergaul ke bawah supaya tau keinginan mereka itu apa, kendalanya cuma satu masih sulit masyarakatnya mengungkapkan pendapat, saya ingin mengembangkan desa bersama-sama bukan untuk saya sendiri Saat ini saya inigin mengembangkan desa dari segi mempertahankan nilai tradisional dan kearifan lokalnya".

Adapun tanggapan yang diberikan oleh informan yaitu Bapak Komang Suweca selaku Kaur Pembangunan di desa Julah menyatakan sebagai berikut:

"Setiap proyek yang direncanakan Bapak Kepala Desa selalu didiskusikan dan selalu berusaha untuk menyimak aspirasi masyarakat. Masyarakat Desa Julah juga beberapa ada yang mau memberikan masukan atau tanggapan dari setiap fasilitas yang perlu dibenahi dan akan selalu ditanggapi bapak kepala desa". 
Adapun tanggapan yang diberikan oleh informan yaitu Bapak Ketut Sidemen selaku Kelian Adat (Tetua) di Desa Julah menyatakan sebagai berikut:

"Menurut saya bapak kepala desa yang sekarang masih berfokus pada pembangunan fisik. Kepala Desa saat ini juga baru menjabat selama satu tahun jadi masih banyak yang mesti dilakukan. Untuk partisipasi masyarakat sekarang sudah membaik, hal ini dibuktikan dengan masih banyak masyarakat yang mau peduli mengurus adat. Kepala Desa juga sudah mau mendiskusikan proyek yang akan dilaksanakan dengan saya selaku kelian adat"

Adapun tanggapan yang diberikan informan yaitu dari salah satu warga di Dusun Kawanan yaitu Bapak Ketut Sedeng menyatakan sebagai berikut:

"Menurut saya Kepala Desa yang sekarang lebih bisa dipercaya dari pada Kepala Desa yang sebelumnya. Kepala Desa yang sekarang lebih mau berbaur dengan masyarakat sehingga saya sebagai warga tidak segan untuk menyampaikan setiap keluhan yang saya alami".

Adapun tanggapan yang diberikan informan yaitu lainnya dari warga Dusun Kawanan mengenai Paartisipasi masyarakat dalam pembangunan menurut Made Ayu Ningsih menyatakan sebagai berikut:

"Proyek yang dibuat Kepala Desa yang sekarang beberapa sudah terlaksana karena kan beliau baru memimpin selama satu tahun, Kinerjanya belum terlihat secara maksimal, Untuk partisipasi saya selaku masyarakat, saya mendukung setiap proyek yang dibuat Kepala Desa asalkan bermanfaat bagi masyarakat".

Adapun tanggapan dari salah satu warga dari Dusun Kanginan mengenai Partisipasi masyarakat dalam pembangunan menurut Nyoman Mirah menyatakan sebagai berikut: Proyek yang dibuat Kepala Desa yang sekarang mungkin sudah terlaksana ya,tapi belum 100\% seperti yang saya katakan tadi proyek yang sudah rampung di dusun kami itu adalah perbaikan jalan dan pemasangan puping.

Adapun tanggapan lainnya dari warga Dusun Kanginan mengenai Partisipasi masyarakat dalam pembangunan menurut Putu Warcana menyatakan sebagai berikut:

Proyek yang dibuat Kepala Desa yang sekarang sudah terlaksana walau belum semuanya selesai, proyek yang sudah selesai itu adalah perbaikan jalan,dan pemasangan puping.

Adapun tanggapan dari salah satu warga dari warga Dusun Batu Gambir mengenai Partisipasi masyarakat dalam pembangunan menurut Wayan Gina menyatakan sebagai berikut:

Menurut saya tidak ada proyek apa, untuk pembangunan di Dusun ini. Karena memang benar apa adanya disini belum ada pembangunan untuk kemajuan dusun ini, selain itu jika ada paruman atau rapat dusun batu gambir tidak pernah di undang.

Adapun tanggapan lainnya dari warga Dusun Batu Gambir mengenai Partisipasi masyarakat dalam pembangunan menurut Ketut Carini menyatakan sebagai berikut:

Seperti yang saya bilang tadi, di dusun ini belum ada proyek yang berkualitas, untuk mendapatkan air saja disini susah, seharusnya kepala desa sudah merencankan proyek untuk membantu dusun kami agar bisa memproleh air secara mudah.

\section{Partisipasi eksekusi (execution participation)}


Adalah partisipasi pada tingkat pelaksanaan. Adapun tanggapan yang diberikan oleh informan yaitu Kepala Desa di Desa Julah Bapak Ketut Kanis Tanaya yang menyatakan sebagai berikut:

"Beberapa proyek yang sudah terlaksana selama periode saya diantaranya perbaikan jalan, pembuatan paping, dan pembuatan got. Dan masih ada pula beberapa proyek yang masih dalam proses pengerjaan. Masyarakat saya beberapa ada yang mau berpartisipasi meskipun tingkat partisipasinya masih kurang. Misalnya pada saat pembuatan got masyarakat turut berpartisipasi menggali tanah tanpa disuruh".

Adapun tanggapan yang diberikan oleh informan yaitu Bapak Komang Suweca selaku Kaur Pembangunan di desa Julah menyatakan sebagai berikut:

"Proyek yang sudah terlaksana dalam kepemimpinan Bapak Kepala Desa yang sekarang diantaranya perbaikan jalan, pembuatan paping, dan pembuatan got. Masyarakat juga mulai menyadari untuk turut berpartisipasi dalam pembangunan desa meskipun masih sedikit".

Adapun tanggapan yang diberikan oleh informan yaitu Bapak Ketut Sidemen selaku Kelian Adat (Tetua) di Desa Julah menyatakan sebagai berikut:

"Proyek kepala Desa yang sekarang masih berfokus dalam pembangunan fisik. Karena baru menjabat selama satu tahun untuk urusan ke adat masih belum maksimal. Namun, Kepala Desa juga sudah mau mendiskusikan proyek yang akan dilaksanakan dengan saya selaku kelian adat. Partisipasi masyarakat terhadap setiap proyek yang dibuat kepala desa juga sudah meningkat".

Adapun tanggapan yang diberikan informan yaitu dari salah satu warga di Dusun Kawanan yaitu Bapak Ketut Sedeng menyatakan sebagai berikut:

"Selama ini saya sudah mulai merasakan manfaat dari proyek-proyek yang dikeluarkan kepala Desa. Jalan di depan rumah saya sudah diperbaiki. Sekarang saya lebih bisa untuk menyampaikan aspirasi saya ke kepala desa. Keinginan Saya turut berpartisipasi dalam pembangunan sehingga saya membantu dalam penggalian tanah ketika ada proyek pembuatan got dan saya juga sering ikut dalam kegiatan gotong royong.

Adapun tanggapan yang diberikan informan yaitu lainnya dari warga Dusun Kawanan mengenai Paartisipasi masyarakat dalam pembangunan menurut Made Ayu Ningsih menyatakan sebagai berikut:

"Saya merasa bahwa saat ini pembangunan di desa Julah lebih meningkat. Sekarang jalan-jalan sudah diperbaiki dan sudah ada pembuatan got. Tingkat partisipasi masyarakat juga sedikit lebih baik dan mau mendukung setiap kebijakan yang dikeluarkan kepala desa karena kepala desa yang sekarang mau untuk berbaur dengan masyarakat.

Adapun tanggapan yang diberikan informan yaitu lainnya dari warga Dusun Kanginan mengenai Paartisipasi masyarakat dalam pembangunan menurut Nyoman Mirah menyatakan sebagai berikut:

"Saya selaku masyarakat di sini juga sangat merasa senang atas perubahan yang terjadi semenjak bapak ketut kanis tanaya menjabat sebagai kepala desa, saya juga sangat senang karena beliau cepat bisa beradaptasi dengan warga sekitar dan tidak pandang bulu menghadapi perlakuan antara masyarakat satu dengan lainnya".

Adapun tanggapan yang diberikan informan yaitu lainnya dari warga Dusun Kanginan mengenai Paartisipasi masyarakat dalam pembangunan menurut Putu Warcana menyatakan sebagai berikut: 
"disini saya merasa sudah meningkatnya kesadaran dari bapak kepala desa dalam upaya meningkatkan kesejahtraan dan kesehatan dari para warganya, dimana dengan adanya pembuatan got limbah dari masing-masing rumah tangga sudah dapat teratasi dengan pembuatan got limbah-limbah tersebut langsung mengalir ke tempat pembuangan akhir.dan juga dengan adanya pembuatan paping lalu lintas disini sudah semakin membaik".

Adapun tanggapan yang diberikan informan yaitu lainnya dari warga Dusun Batu Gambir mengenai Partisipasi masyarakat dalam pembangunan menurut Wayan Gina menyatakan sebagai berikut:

"disini saya belum bisa merasakan proyek yang telah terjadi di desa akibat jarak dari desa ke dusun kami sangatlah jauh sehingga di dusun kami sama sekali belum merasakan proyek yang telah terlaksana seperti pembuatan got dan pembuatan paping".

Adapun tanggapan yang diberikan informan yaitu lainnya dari warga Dusun Batu Gambir mengenai Partisipasi masyarakat dalam pembangunan menurut Ketut Carini menyatakan sebagai berikut:

"Menurut saya kinerja dari kepala desa sekarang memang sudah berjalan namun kami yang dari dusun batu gambir sama sekali belum bisa merasakannya akibat jarak dari dusun kami menuju desa lumayan jauh dan kepala desa juga belum melakukan pembuatan got ataupun pembuatan paping disini".

\subsection{Peran Kepala Desa dalam Meningkatkan Partisipasi Masyarakat dalam Pembangunan}

Dalam hal ini Kepala Desa selaku pemimpin tertinggi di desa dapat dilihat fungsi kepemimpinan kepala desa, dengan indikator:

\section{Fungsi Instruktif}

Adalah fungsi yang menjelaskan bagaimana cara Pemerintah Desa dalam hal ini adalah Aparat Desa dalam menentukan perintah maupun mengerjakan perintah. Untuk mengetahui peran Kepala Desa dalam meningkatkan partisipasi masyarakat dalam pembangunan di Desa Julah kami mewawancarai pihak-pihak seperti Kepala Desa Julah, Kelian adat (Tetua Adat) di Desa Julah, Kaur Pembangunan di Desa Julah, dan masyarakat yang ada di Desa Julah masing-masing dua orang untuk setiap dusun yang ada yaitu di Dusun Kawanan, Dusun Kanginan dan Dusun Batu Gambir. Untuk hasil dari wawancara kami dapat dilihat hasilnya sebagai berikut:

Adapun tanggapan yang diberikan oleh informan yaitu Bapak Ketut Kanis Tanaya selaku Kepala Desa yang menyatakan sebagai berikut:

"Menurut saya dalam menentukan perintah maupun mengerjakan perintah apakah perintah tersebut cocok diterpakan di desa julah, dan dialokasikan untuk apa saja dan tentunya harus sesuai dengan aturan yang sudah ada. Dan dalam mengerjakan perintah tersebut tentunya harus sesuai dengan aturan yang istilah tidak ada diluar aturan yang ada dan sesuai dengan alokasi yang ditentukan".

Adapun tanggapan yang diberikan oleh informan yaitu Bapak Komang Suweca selaku Kaur Pembangunan di desa Julah menyatakan sebagai berikut:

"Menurut saya setiap rencana proyek yang dibuat oleh kepala desa, saya selaku Kaur pembangunan juga turut memberikan saran misalnya seperti pembuatan got yang sudah rampung bulan sebelumnya yaitu bulan oktober, pemasangan paping yang belum rampung dan tahap pengerjaan baru 50\%, kepala desa selalu berkoordinasi dan mengawasi proyek agar target penyelesaian proyek tepat waktu agar tidak menyalahi aturan yang sudah ditetapkan dari pusat".

Adapun tanggapan yang diberikan oleh informan yaitu Bapak Ketut Sidemen selaku Kelian Adat (Tetua) di Desa Julah menyatakan sebagai berikut: 
"Menurut beliau kepala desa sekarang lebih cekatan dan mau berkoordinasi dengan adat, apakah program atau proyek itu sesuai dengan adat dan tradisi desa julah, sehingga dengan dipilah-pilahnya proyek tersebut desa ini bisa tetap ajeg dengan budaya sendiri"

Adapun tanggapan dari salah satu warga yaitu Bapak Ketut Sedeng dari Dusun Kawanan menyatakan sebagai berikut:

"Menurut saya kinerja beliau belum sepenuhnya saya rasakan manfaatnya, karena beliau baru menjabat selama 1 tahun, tetapi sudah ada perubahan sedikit dari sebelumnya seperti pembuatan got, paping jalan dan msih banyak rencanarencana proyek yang akan dilaksanakan oleh beliau seperti pembuatan tong sampah, Balai banjar."

Adapun tanggapan dari salah satu warga di kawanan yaitu lbuk Made Ayu Ningsih menyatakan sebagai berikut:

"Menurut saya kinerja beliau bagus-bagus saja, alasanya ya beliau sering turun lansung untuk mencari aspirasi dari para masyarakat seperti saya. Dan beliau juga mau untuk lebih mengakrabkan diri kepada masyarakat"

Adapun tanggapan dari salah satu warga di Dusun Kanginan yaitu Nyoman Mirah menyatakan sebagai berikut:

"kalau saya apapun yang kepala desa katakana, saya selaku masyarat menuruti apa yang beliau selagi itu untuk membangu desa, selama ini belau selalu merangkul masyarakat untuk membuat perubahan di desa seperti menginstrusikan untuk gotong royong guna memperbaiki got "

Adapun tanggapan dari salah satu warga di Dusun Kanginan yaitu Putu Warcana menyatakan sebagai berikut:

"menurut saya kepala desa yang sekarang mau berkoordinasi kepada masyarakat tentang apa saja program kerja yang akan dilakukan, saya selaku masyarakat merasa dekat dengan kepala desa karena beliau sering bersosialisasi dengan masyarakat".

Adapun tanggapan dari salah satu warga di Dusun batu gambir yaitu Wayan Gina menyatakan sebagai berikut:

"kalau saya biasa-biasa saja, karena beliau baru menjabat, jadi saya tidak berani untuk berbicara banyak tentang kinerja beliau"

Adapun tanggapan dari salah satu warga di Dusun batu gambir yaitu Ketut Carini menyatakan sebagai berikut:

"menurut saya, sejak beliau menjabat sebagai kepala desa saya lihat di dusundusun yang lain sudah ada perubahan, tetapi di dusun saya belum dapat merasakan kinerjanya, saya berharap kedepannya d dusun saya ada perbaikan untuk mendapatkan air bersih".

\section{Fungsi Kumulatif}

Adalah fungsi yang dimiliki oleh Pemerintah Desa dalam hal ini Aparat Desa ataupun Kepala Desa terhadap bagaimana cara menetapkan keputusan terutama menyangkut masalah desa. Adapun tanggapan yang diberikan oleh informan yaitu Bapak Ketut Kanis Tanaya selaku Kepala Desa yang menyatakan sebagai berikut:

"Selama saya menjabat setiap kebijakan proyek yang dibuat telah melalui musyawarah terlebih dahulu. Saya menjalankan proyek berdasarkan arahan dari atasan. Sebelum keputusan dilaksanakan saya juga selalu membicarakannya kepada masyarakat dalam paruman desa. Karena dalam pengambilan keputusan tersebut tidak hanya dengan persetujuan dari perangkat desa saja melainkan dengan masyarakat umum dan pihak Adat Desa Julah sendiri. Sehingga 
keputusan ini diketahui tidak hanya oleh pihak perangkat desa saja. Jadi wajib dalam menentukan keputusan harus menyertakan masyarakat umum.

Adapun tanggapan yang diberikan oleh informan yaitu Bapak Komang Suweca selaku Kaur Pembangunan di desa Julah menyatakan sebagai berikut:

"Dalam menentukan keputasan terkait pemerintahan desa, yang dijadikan dasar adalah dengan melalui pertemuan atau rapat - rapat desa terkait pembangunan desa sendiri. hal ini dilakukan agar tidak terdapat keputusan sepihak. Sehingga dampak baik dan buruk dari keputusan itu sendiri tidak hanya diterapkan oleh pihak perangkat desa. dan tentunya keputusan ini juga harus melibatkan masyarakat umum dan pihak adat Desa Julah sendiri."

Adapun tanggapan yang diberikan oleh informan yaitu Bapak Ketut Sidemen selaku Kelian Adat (Tetua) di Desa Julah menyatakan sebagai berikut:

"Keputusan yang dibuat oleh pemerintah desa baik berupa lisan maupun tertulis harus diketahui juga oleh masyarakat umum dan pihak adat sendiri. Sebab Adat juga merupakan lembaga pemerintahan desa. sehingga keputusan itu akan sejalan dengan pihak Dinas dan pihak Adat."

Adapun tanggapan dari salah satu warga di Dusun Kawanan yaitu Bapak Ketut Sedeng menyatakan sebagai berikut:

"Dalam proses pengambilan keputusan memang terletak pada pemerintah desa, namun keputusan tersebut juga harus diperhitungkan dengan masyarakat sendiri. Sehingga masyarakat tau akan keputusan terkait pembangunan desa“

Adapun tanggapan dari salah satu warga di Dusun kawanan yaitu Ibuk Made Ayu Ningsih menyatakan sebagai berikut:

"Dalam pembuatan keputusan yang terkait dengan permasalahan desa masyarakat harus dilibatkan pula Kepala desa yang sekarang sudah memperhatikan hal ini namun masih perlu ditingkatkan lagi sehingga kedepannya tingkat partisipasi masyarakat akan semakin meningkat".

Adapun tanggapan dari salah satu warga di Dusun Kanginan yaitu Putu Warcana menyatakan sebagai berikut:

"Menurut saya dalam pengambilan keputusan disini harusnya kepala desa juga mempertimbangkan pendapat dan aspirasi dari masyarakat. Karena menurut saya sejauh ini pendapat dari para kaur dan yang berfungsi banyak didesa saja yang diutamakan".

Adapun tanggapan dari salah satu warga di Dusun Kanginan yaitu Nyoman Mirah menyatakan sebagai berikut:

"Dalam pengambilan keputusan untuk kemajuan didesa ini menurut saya sudah berjalan baik namun ada juga beberapa kendala yang kerap kali muncul pada saat pelaksanaan, mungkin karena dalam pengambilan keputusan tersebut masih banyak warga yang tidak memperhatikan sekali".

Adapun tanggapan dari salah satu warga di Dusun Batu Gambir yaitu Wayan Gina menyatakan sebagai berikut:

"Kalau menurut saya dalam pengambilan keputusan didesa aspirasi dari masyarakat kurang diperhatikan sekali, mungkin karena kami belum dipercaya oleh kepala desa atau mungkin beliau masih mengutamakan pendapatnya sendiri".

Adapun tanggapan dari salah satu warga di Dusun Batu Gambir yaitu Ketut Carini menyatakan sebagai berikut: 
"Menurut saya pengambilan keputusan didesa masih mengutamakan orangorang yang berguna saja didesa, seperti kaur ataupun perangkat adat dan desa saja sehingga pendapat yang dari masyarakat belum banyak yang diterima".

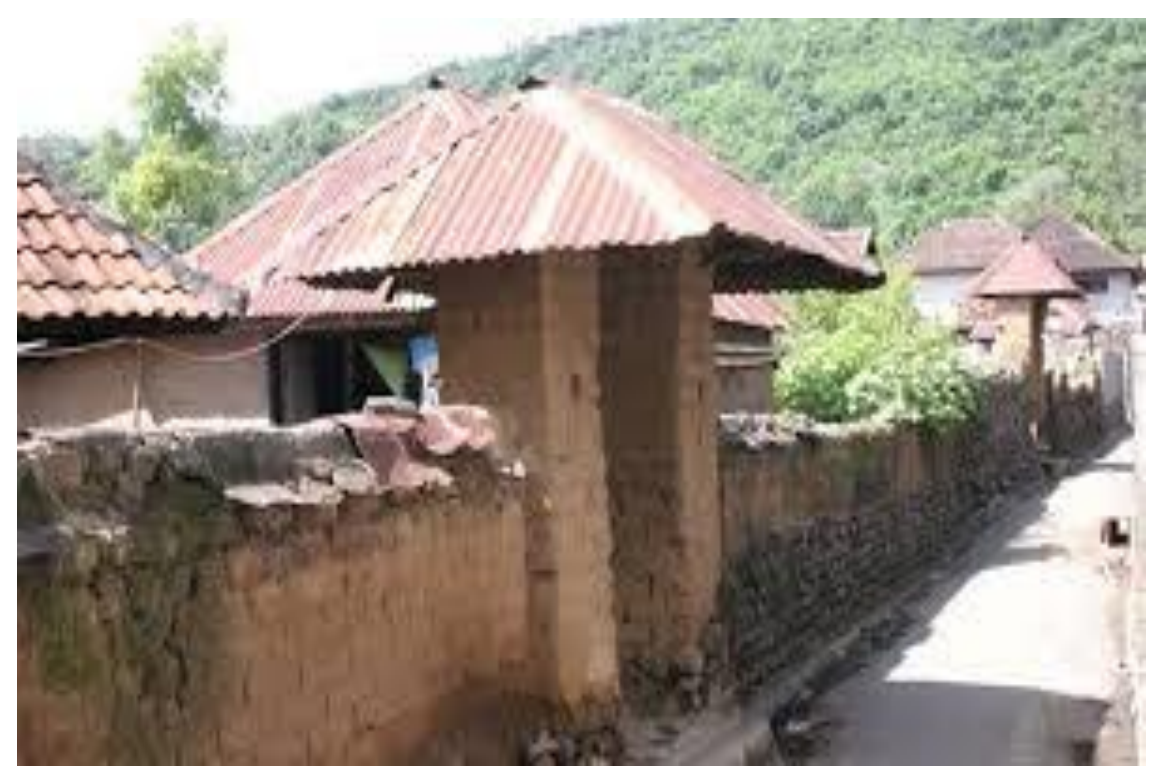

Gambar 01

Pada Gambar 01 menunjukan keadaan rumah masyarakat di Desa Julah sebelum adanya perbaikan. Dimana salah satu ciri khas rumah warga di Desa Julah adalah adanya Angkul-Angkul. Dalam gambar terlihat belum ada perbaikan, dimana jalanan disana juga masih belum diperbaiki.

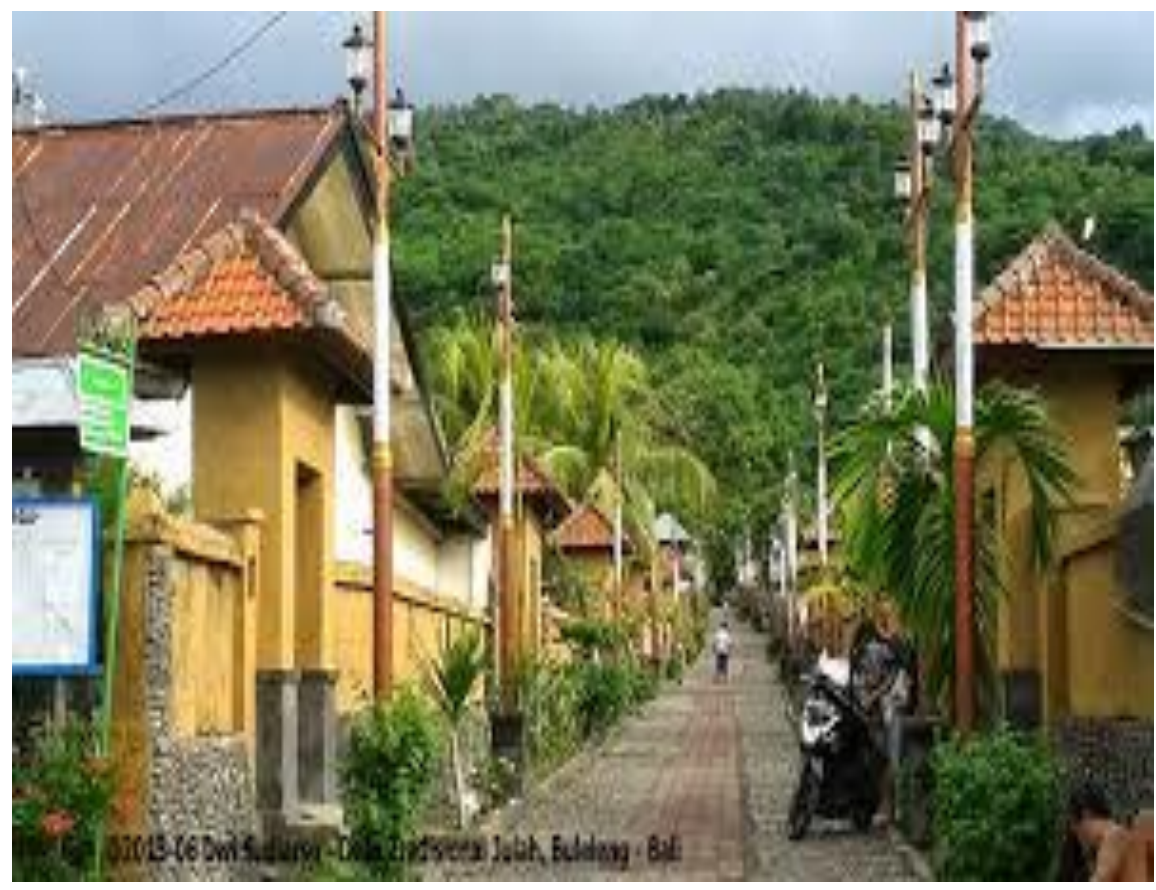

\section{Gambar 02}

Pada Gambar 02 menunjukan keadaan rumah masyarakat di Desa Julah setelah adanya bantuan perbaikan. Dalam gambar terlihat telah adanya banyak perubahan dimana salah satu ciri khas rumah warga di Desa Julah adalah adanya Angkul-Angkul telah dirubah 
dengan lebih baik. Jalanan sekitar juga sudah di paping sehingga lebih baik dari sebelumnya. Namun dengan adanya perubahan ini, terdapat pendapat dari Kelian adat Desa Julah yaitu Bapak Ketut Sidemen yang beranggapan bahwa perbaikan ini kurang sesuai dengan adat tradisi yang seharusnya, dimana angkul-angkul diperbaiki bukan oleh masyarakat desa Julah melainkan dileelang oleh tender sehingga perbaikannya tidak sesuai dengan adat budaya yang ada. Dan dari pengamatannya, beliauu juga mengatakan bahwa paping di jalan dibeberapa tempat di Desa Julah yang mulai rusak dan mengganggu kenyamanan pengguna jalan.

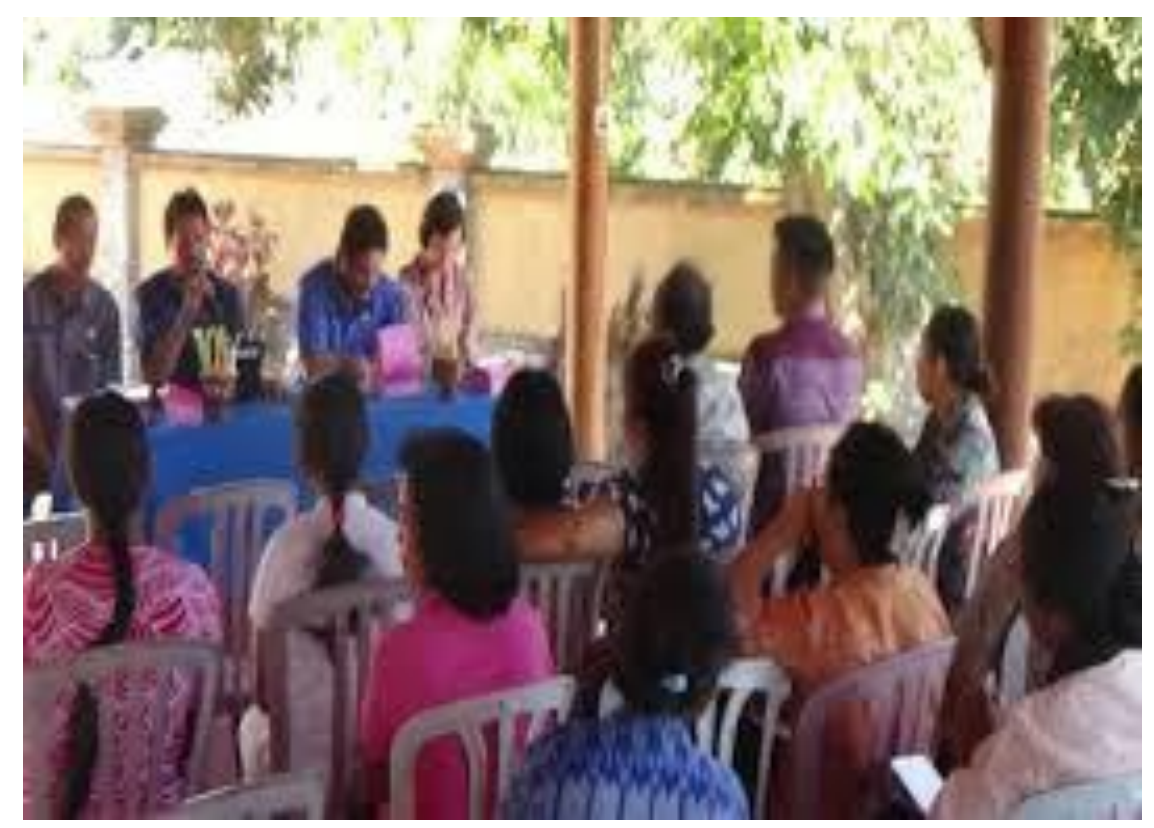

Gambar 03

Pada Gambar 03 menunjukan pada saat diadakan Rapat atau Paruman Desa di Balai Banjar Desa Julah. Dimana dalam Paruman tersebut biasanya dihadiri oleh Kepala Desa, Kelian Adat, Perangkat desa, Kelian dusun, BPD dan beberapa masyarakat. Paruman biasanya dilakukan dalam rangka mensosialisasikan rencana program dari desa. Dalam paruman di desa Julah, masyarakatnya belum semua mau datang dan berpartisipasi. Kalaupun mereka datang namun masih banyak yang "Ngekoh Ngomong". 


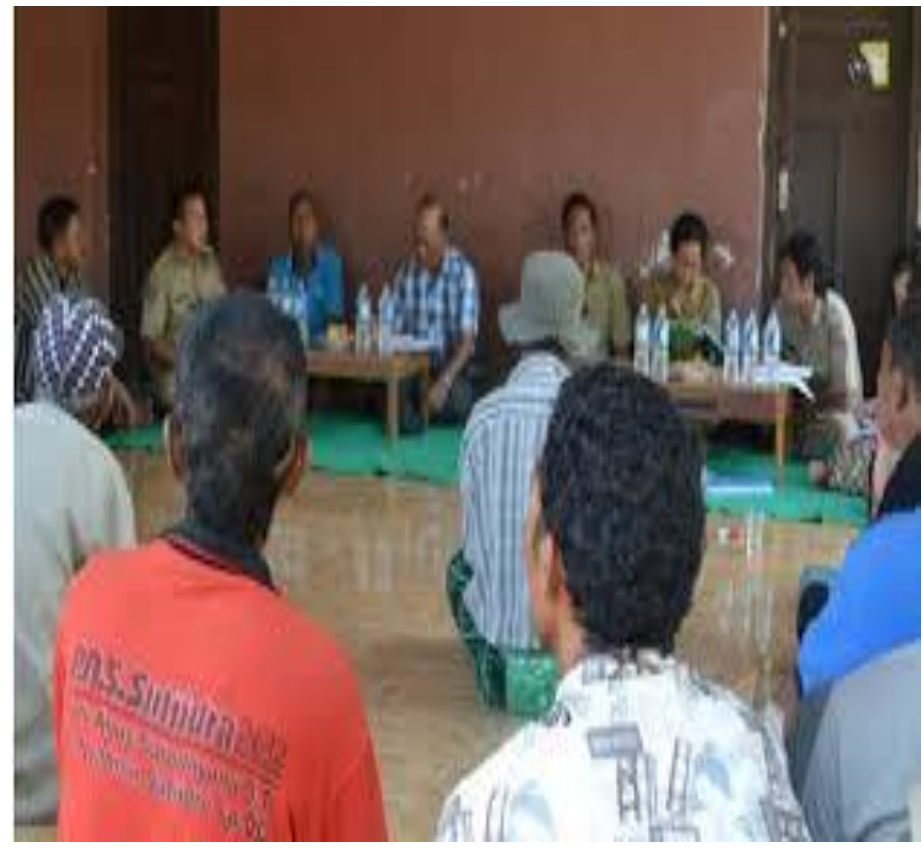

Gambar 04

Pada Gambar 04 menunjukan Kegiatan paruman adat di Desa Julah yang dimana kegiatan paruman ini dihadiri oleh Kelian adat, Kepala Desa, Kelian Dusun, dan masyarakat adat. Di desa Julah, Paruman adat biasanya dilakukan setiap bulan tilem setiap bulannya, dimana paruman ini dilakukan untuk membicarakan rencana Upacara di Pura Desa atau Balai Agung. Masyarakat Julah akan lebih partisipatif apabila membahas tentang kegiatan adat. Karena mereka merasa bahwa tanggung jawab kepada adat itu bukan hanya tanggung jawab secara Lahir tetapi juga Bathin kepada sesuunan Ida Sang Hyang Widhi Wasa.

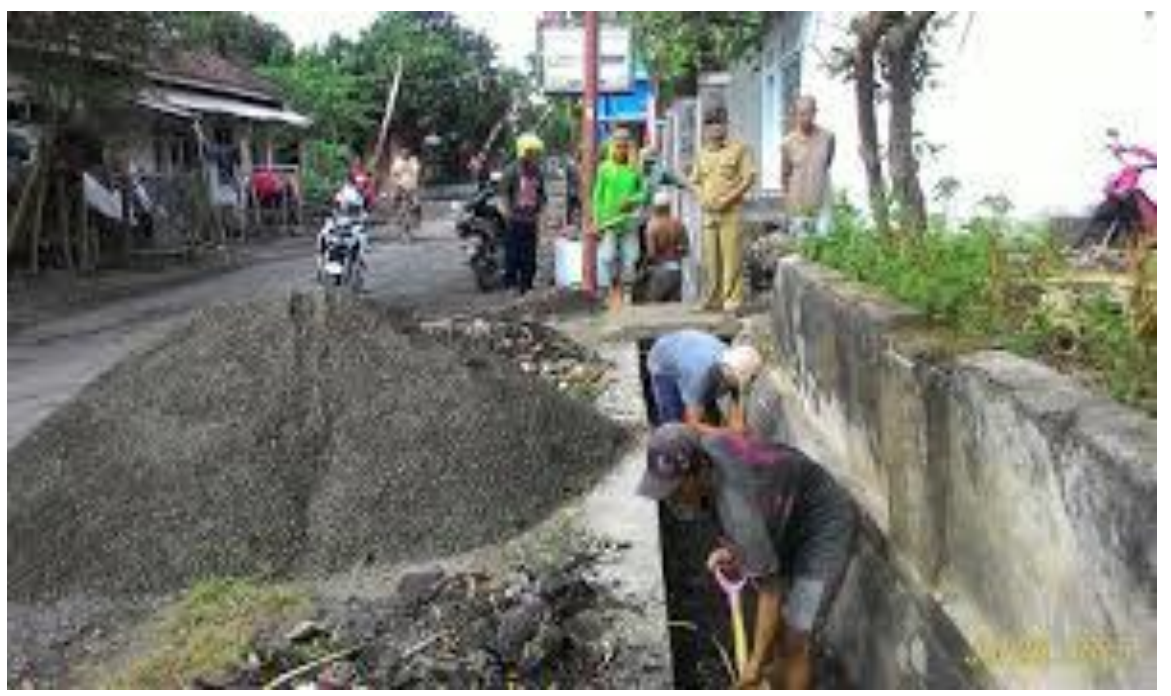

\section{Gambar 05}

Pada gambar 05 menunjukan salah satu proyek pembangunan yang dilakukan di Desa Julah yaitu pembuatan Got. Didalam gambar terlihat partisipasi masyarakat dalam penggalian got. Dalam kegiatan pembuatan got ini diawasi oleh Bapak kepala desa, Kepala Dusun, BPD dan Kaur Pembangunan. Dalam setiap proyek yang direncanakan oleh Kepala Desa, beberapa masyarakat mau ikut berpartisipasi, Namun masih banyak pula yang belum mau berpartisipasi sehingga kedepannya Bapak Kepala Desa mengharapkan tingkat partisipasi masyarakat lebih ditingkatkan. 


\section{Simpulan dan Saran}

Kesimpulan dari Partisipasi Masyarakat Desa Julah Dalam Pembangunan

Seperti yang telah diuraikan pada hasil dan pembahasan pada bab sebelumnya, maka dapat disimpulkan bahwa tingkat partisipasi masyarakat di Desa Julah dalam pembangunan sudah mulai meningkat walaupun masih sedikit. Masyarakat Desa Julah masih ada yang belum merasa memiliki tanggungjawab untuk sama-sama memajukan desa. Dimana sebuah desa akan dapat maju apabila ada partisipasi dari masyarakat. Sejauh ini selama masa kepemimpinan kepala desa Ketut Kanis Tanaya pandangan dari beberapa masyarakat sekitar mulai berubah. Hal ini dibuktikan dengan mulai optimalnya pembangunan di Desa Julah. Pembangunan seperti pembuatan got, pembuatan paping, perbaikan jalan, perbaikan angkul-angkul, dan perbaikan balai banjar yang masih dalam tahap perbaikan. Dari semua program yang dicanangkan pemerintah desa, Masyarakat di Desa Julah dapat berpartisipasi dalam beberapa hal, misalnya pada saat proses pembuatan got, masyarakat membantu menggali untuk dibuat got. Masyarakat juga beberapa sering turut dalam gotong royong untuk pembersihan desa dan turut dalam rapat desa atau paruman desa yang diadakan. Sehingga dapat disimpulkan bahwa tingkat partisipasi masyarakat di Desa Julah sudah mulai ada peningkatan hanya saja masih perlu ditingkatkan.

Kesimpulan dari Peran Kepala Desa Dalam Meningkatkan Partisipasi Masyarakat Desa Julah

Kepala Desa Julah Ketut Kanis Tanaya yang telah menjabat selama satu tahun telah melaksanakan tugas dan tanggung jawabnya untuk memajukan desa dan meningkatkan tingkat partisipasi masyarakat desa Julah dalam pembangunan. Selama ini, Kepala Desa telah berusaha untuk mengakomodir setiap saran dari masyarakat hanya saja belum secara merata. Masyarakat yang tinggalnya jauh dari pusat desa masih susah untuk menyampaikan keluhan yang dihadapi kepada kepala desa. Masyarakat di Dusun Batu gambir masih banyak yang tidak aktif berpartisipasi dalam pembangunan. Kepala Desa masih berfokus dalam pembangunan fisik dan hanya melaksanakan perintah dari atas dalam setiap proyek yang akan dilaksanakan. Seperti sekarang ini, rencana perbaikan bale banjar yang belum rampung karena dana yang diperoleh dari pusat masih belum cair. Kepala desa juga masih harus meningkatkan kerjasamanya dengan adat karena selama ini pemerintahan desa dan kelian adat belum maksimal untuk bekerja sama dalam membangun desa. Meskipun demikian, Kepala desa saat ini sudah lebih baik karena mau datang setiap rapat atau paruman yang diadakan oleh adat. Dan salah satu hal yang masih menjadi tantangan besar bagi kepala desa di Desa Julah adalah dimana desa ini merupakan salah satu desa tertua yang memiliki nilai sejarah tinggi di Buleleng yang mesti dijaga. Kepala desa jangan terus berfokus dalam memajukan desa namun tetap juga harus mempertahankan adat budaya yang ada agar julukan desa julah sebagai desa tradisional yang kaya sejarah dapat terus dipertahankan. Sehingga salah satu hal yang mesti terus dipertahankan adalah nilai dari adat budaya tradisi para leluhur di Desa Julah.

Berdasarkan pemaparan diatas, saran yang dapatdiberikan adalah dengan adanya ulasan penelitian mengenai Peran Kepala Desa dalam Meningkatkan Partisipasi Masyarakat Dalam Pembangunan Desa di Desa Julah ini diharapkan kedepannya penulis dapat melakukan penelitian yang sejenis ataupun tidak dengan ulasan materi yang lebih baik dan lebih menarik lagi. Dengan adanya penulisan mini riset ini diharapkan dapat memberikan penulis pengalaman dalam menulis jurnal ilmiah yang tentunya akan sangat bermanfaat bagi penulisan skripsi penulis kedepannya, untuk masyarakat Desa Julah kedepannya diharapkan untuk meningkatkan partisipasinya dalam pembangunan Desa. Karena Sebuah desa akan maju apabila ada partisipasi aktif dari masyarakat. Jangan lagi mengatakan "Koh Ngomong", sampaikan setiap aspirasi kepada kepala desa. Dan juga selain dalam hal pembangunan, masyarakat desa Julah juga tetap harus turut mempertahankan nilai adat dan budaya leluhur desa selaku desa tradisional agar tetap ajeg. Semoga kedepannya masyarakat desa Julah lebih peduli terhadap setiap kemajuan desa dan bersama-sama dengan Kepala Desa untuk mempertahankan desa tradisional Julah yang kaya akan tradisi, dan untuk Kepala Desa Julah kedepannya diharapkan untuk terus meningkatkan kinerjanya 
untuk mewujudkan visi Desa Julah yaitu Mewujudkan masyarakat julah yang sejahtera berlandaskan konsep Tri Hita Karana. Dan mewujudkan Misi Desa Julah untuk Meningkatkan kesejahteraan sosial ekonomi masyarakat yang berkeadilan, Meningkatkan kualitas sumber daya manusia, Meningkatkan ketaqwaan kepada Tuhan Yang Maha Esa, Meningkatkan persatuan dan kesatuan atas dasar saling hormat menghormati intern dan antar umat beragama, dan Meningkatkan pelestariana lingkungan. Semoga kedepanya ada komunikasi yang baik antara Kepala desa dengan Kelian adat dan masyarakat untuk mempertahankan desa tradisional Julah yang kaya akan tradisi. Sehingga terwujud siistem pengelolaan pembangunan di desa bersama-sama secara musyawarah, mufakat, dan gotong royong

\section{DAFTAR PUSTAKA}

Kasmiah. 2014. Peranan Pemerintah Desa Untuk Meningkatkan Partisipasi Masyarakat Dalam Pembangunan (Studi Kasus Di Desa Mantang Besar Kecamatan Mantang Kabupaten Bintan). Fakultas IImu Sosial Dan Politik. Universitas Maritim Raja Ali Haji Tanjung pinang.

Ginting, Herawati. 2014. Peranan Kepemimpinan Kepala Desa Dalam Meningkatkan Partisipasi Masyarakat Dalam Pembangunan Fisik (Studi Pada Kantor Kepala Desa Palding Jaya Sumbul Kecamatan Tigalingga Kabupaten Dairi) . Fakultas IImu Sosial Dan Politik Universitas Sumatera Utara.

Prayudi, Made Aristia dan Komang Adi Kurniawan Saputra. (2016). Akuntansi Pemerintahan. Buku Ajar. Singaraja: Undiksha Press (PS). 